\title{
Research on Student Management Innovation in the Background of Informationization
}

\author{
Hainan Li \\ Zhuhai College of Jilin University, Zhuhai, Guangdong, 519041
}

Keywords: Student Management; Informationization; Management Method

\begin{abstract}
With the rapid development of China's economy and society, informatization has gradually evolved into the theme of all aspects of social production and life. The informationization of colleges and universities is an important part of educational informationization. Therefore, it is necessary to study the innovation of college student management under the background of informationization. This paper elaborates the important role of college student management in the context of informationization and the problems in the management process. It also proposes targeted strategies for the innovation of college student management.
\end{abstract}

\section{Introduction}

With the rapid economic and social development, informatization has become the main trend of current social development. The development of informatization has led to the reform of China's political, economic, and cultural undertakings. The advent of the information age has brought tremendous results to all aspects of today's social production and life. Impact. The education of students in colleges and universities is an important cornerstone for the prosperity of the country. The management of college students is also affected by the development of informationization. The popularization of informatization has greatly facilitated the students' learning and living, and at the same time greatly improved the efficiency of the college student management department. Informationization has promoted the construction of digital campuses in colleges and universities, and achieved the integration of student affairs management, teacher teaching, and academic research. In addition, informatization provides innovative ideas for colleges and universities personnel training model, promotes colleges and universities to keep pace with the times, continuously adapt to social development and needs in the new period, and cultivate more high-level talents to stand out in social competition and contribute to social and economic development. Its own strength, and the transformation of the talent cultivation model will in turn drive the development of university information management.

\section{Problems in College Student Management Innovation in Informationization}

Student management is not scientific enough. At present, the management of university students is centered on managers, ignoring the student-dominated status and indifferent to the students' service consciousness. When managing students, they are often accustomed to using administrative teaching methods to allow students to passively accept knowledge. In this passive situation, the lack of initiative of the students, the development of the student's personality is constrained, the college students are already adults, they have their own thinking, can quickly understand any new things, so the management of students Should be more innovative features, not too rigid and impede the development of students, can not only manage as the main goal, but neglect the service of students, because of the long-term development of students, to promote students and colleges with scientific and rational management model The common progress.

The student management system is incomplete. The current university student management system mainly includes four aspects: schools, departments, students and society. Management departments and agencies supervise and administer students, and various agencies and agencies collaborate with each other to carry out management work. Chinese colleges and universities 
manage students in a systematic manner, and students are managed in a combined system. Universities, students, and society A management system was also established, but this system was too one-sided and did not provide in-depth management services to students. The students' understanding of the school's rules and regulations is difficult to understand and may even cause irritability. Fundamentally, students should be subject to management, and they should actively follow the school rules, be strict with themselves, and study hard.

The quality of student management workers is lacking. There is a direct relationship between the innovative construction of college students' management work and the overall quality of management personnel. Although management personnel are constantly learning and improving themselves in the age of information, most workers lack the initiative in the learning process. Knowledge is not mastered enough. Most managers also passively learn innovative knowledge. In the management of students, the traditional rigid management model is still used, which directly affects the innovative development of student management. Management workers are the leaders of students' life. They must clearly define their own responsibilities and functions, and continue to learn. Innovative management mode, self-improvement.

\section{The Necessity of Innovating Student Management Model in Informationization}

Informatization has been subtly integrated into all areas of social life and has had a significant impact on people's lives. The university as a driving force for the trend of the times naturally should stand at the forefront of the times and innovate in the management of college students to adapt to the needs of the times. Colleges and universities in the construction of university information in the need to change the original management methods; and innovative management functions, the use of new information management tools to manage students. In terms of the student's future, the digitization of student information enables students' information to be quickly and completely transmitted to the students' new employment environment so that they can start a new job smoothly. The ultimate goal of the construction of university informatization is to optimize the student management model and lay a good foundation for the school's work. It also can provide more convenient services for students. In addition, the construction of various contents of university information construction is an indispensable part of the university's management system, and it is also an inexhaustible motive force to promote the continuous innovation and development of colleges and universities.

In the process of student management work, attention is paid to the introduction of digitization, the use of information methods to manage students' daily work, improve student work efficiency, and improve methods for carrying out student work, overcome shortcomings in traditional student management work, and promote student management work. development of. Constructing a student management informationization model can strengthen the connection between students and workers, facilitate information sharing, strengthen student work exchanges, improve work insufficiency, and promote students to work more clearly in the division of labor, and more systematically, so that student management can be promoted to a new level. Level.

With the increase in the number of students in colleges and universities, the management of college students is also more complicated and their functions have increased. This has caused students to work in a complex way. If schools simply use manual work to deal with student work, the total work efficiency will be low. The school's student management work is the basic mechanism for the normal operation of the school. If the mechanism has problems, it will affect the work of the school and make the whole situation in trouble. Many business affairs in college student management work need to convey information in a timely and accurate manner. These tasks always pass through many links in the process of communication, for example, from the school to the various colleges and then from the college to the various departments, and ultimately communicate Each classmate in the class is complicated and takes a long time. On the contrary, if students need various feedbacks, they naturally need to go through the same link, and the efficiency naturally cannot be discussed. After the introduction of an information-based management model, students and student workers can communicate on the same platform, transcending the original process and 
greatly improving work efficiency.

\section{Measures for Student Management Innovation in Informationization}

Student management work should be scientific and reasonable. For colleges and universities informatization management is an effective way to build a digital campus, through the current advanced information technology, the university students' management resources file is further integrated, the management work will become simple and not too heavy, and colleges and universities should be more to the management system. Perfection, as long as a highly efficient and scientific management system can better serve teachers and students. This kind of information management model does not present the traditional management methods to everyone in the form of networks. Instead, it changes traditional management concepts, optimizes management procedures and management organizations, and greatly improves the efficiency of student management. Optimize the innovation and improve the management program to save, so that the future of innovative R \& D, it can also save future R \& D optimization costs.

Continuously improve the information management innovation system. In this era of informationization, the traditional management mechanism of colleges and universities has obvious deficiencies and cannot serve teachers and students better. Therefore, it is necessary to establish a sound management mechanism to satisfy the needs of student management work. The construction of the university's management mechanism mainly includes two aspects, one is the teaching and production information of the mechanical specialty, and the level of communication and communication between the students and the mechanical worker is strengthened so that the students can contact the construction site of the enterprise at the machinery production base. In the environment, enterprises are also more willing to cultivate talents for mechanical specialty students in vocational colleges.

Improve the rules and regulations related to school-enterprise cooperation. At the institutional level, the school-enterprise cooperation mechanism should be improved to improve the level of school-enterprise cooperation between higher vocational colleges and machinery production enterprises. It is more important to further understand the development rules and characteristics of market operations. In the training of mechanical professionals, we must pay more attention to the status quo of the development of the machinery industry and follow the development trend of the machinery industry to carry out education and teaching. At the same time of school-enterprise cooperation, increase the closeness of cooperation between the two parties, and encourage talented mechanical operators to professionally guide the internship situation of mechanical majors in higher vocational colleges. Schools with low degree of cooperation or unclear development direction of schools and enterprises can improve vocational colleges by making full use of the social resources provided by enterprises and developing the collective wisdom of mechanical professional teachers in higher vocational schools by improving the school-enterprise cooperation system. Better scientific research and development projects for mechanical technologies.

Learn from the school-enterprise cooperation mechanism in other countries. For example, studying Germany's "dual system" cooperation mechanism, as well as Australia's "TAFE" talent training model. Higher vocational colleges may choose to establish "professional education groups" when they engage in deep school-enterprise cooperation. That is to say, they specially organize the establishment of a group-type education enterprise and organize the enterprise materials that are intended to carry out school-enterprise cooperation projects. Then carry out school-enterprise cooperation projects on the basis of the education group, and then standardize the specific content of the school-enterprise cooperation, the specific cooperation objectives and the forms of cooperation, etc., and stipulate what each vocational college is responsible for in the school-enterprise cooperation project. This in turn enables close cooperation between higher vocational colleges and machinery production companies.

Improve job qualifications for job placement. Strictly implement the employment access system, and those who fail to pass the qualification assessment for employment can not perform the job, so that intangible one can greatly enhance the competitiveness of students in the economic 
management majors of higher vocational colleges, and also improve the vocational colleges. The school's practical teaching standards are based on the principle of "training and re-employment". During the period of higher vocational education, the dual-assessment project of academic certificates and vocational qualification certificates is actively carried out, which makes higher vocational education and the occupation of mechanical manufacturing enterprises. Education is seamlessly connected so that students can familiarize themselves with the machinery production equipment and machinery production and operation procedures in the enterprise, increase training-based practical new courses, cultivate students' awareness of competition in the production environment of the company and their ability to communicate and collaborate with others. At the study stage of higher vocational education, the future development goals are designed and planned.

\section{Conclusion}

In the implementation of school-enterprise cooperation projects in higher vocational colleges, mechanical education should be combined with the development laws of the local economy, conform to the development trend of the times, and after clarifying the problems existing in the school-enterprise cooperation at this stage, we must actively seek solutions. Problems, and then explore a correct school-enterprise deep cooperation development path, deepen the significance of the development of school-enterprise cooperation, provide more scientific research support and technical support for the development of China's machinery industry, improve the cooperation of mechanical specialty in higher vocational colleges teaching ability.

\section{References}

[1] Shen Haidong, SHEN Shiren. Research and Practice of Higher Vocational School-enterprise Deep Cooperation School-running Model: Taking Economic Major as an Example [J]. Vocational Education Newsletter, 2012, (5).

[2] Ma Shunbin. Construction of long-term mechanism for deep cooperation between school and enterprises in higher vocational colleges [J].Northwest Adult Education Journal, 2011, (6).

[3]Shen Shiren. School-enterprise cooperation in higher vocational commerce business "company system" talent training mode of exploration [J]. Vocational communication, 2011, (21).

[4] Chen Xiaobo, Shi Linxi. Innovation of college student management in the context of informationization [J]. Journal of Weifang Engineering Vocational College, 2014, 05:37-38. 